930:[002.2(477+71+73)«19/20»:[94:356.15(477)«19»] ЛУК'ЯНЧЕНКО С.В.

\title{
ДІЯЛЬНІСТЬ ВИДАВНИЦТВА «ЛІТОПИС УКРАЇНСЬКОЇ ПОВСТАНСЬКОЇ АРМЇ̈»
}

У статті охарактеризовано особливості організації та тематичну наповненість багатотомного видання «Літопис Української повстанської армії» (започаткованого у 1976 р. у Канаді) як найбільшого корпусу друкованих джерел 3 історії Організації українських націоналістів та Української повстанської армії. Показано співпрацю видавництва 3 провідними науковими інституціями незалежної України.

Ключові слова: Канада, Україна, Видавництво «Літопис УПА», український комбатантський рух.

Актуальність проблели. Ветерани Української повстанської армії (УПА), які після Другої світової війни переселилися в США і Канаду, привезли з собою значну кількість документальних матеріалів про діяльність УПА. Більшість цих документів знаходилося в Архіві зарубіжного представництва Української головної визвольної ради (УГВР) у Нью-Йорку.

Комбатантські організації УПА розуміли всю важливість не лише збереження цих унікальних документів, але й необхідність їх видання 3 метою відтворення бойового шляху Української Повстанської Армії. На Х-му делегатському з'їзді в 1973 р. Об’еднання колишніх вояків УПА США і Канади у Детройті було прийнято рішення про збір матеріалів, документів i спогадів учасників УПА і видання їх окремими томами під назвою «Літопис Української Повстанської Армї» («Літопис УПА»). Назва ця, до речі, була взята 3 підпільного військового журналу-одноднівки, виданого на

Лук'янченко Світлана Володимирівна, кандидат історичних наук, доцент кафедри гуманітарних наук, Національна академія сухопутних військ імені гетьмана Петра Сагайдачного, м. Львів.

(C) Лук'янченко С.В., 2017 
циклостилі в жовтні 1947 р. 3 терену воєнної округи УПА-Захід [17, арк. 4; 5, с. 12; 1; 20, с. 102].

Iсторіограбіл проблели. Незважаючи на значимість видання, сучасні українська і заокеанська історіографії, за винятком статей авторства Л. Волянської, П. Потічного, М. Посівнича [1; 14], не приділили належної уваги організаційним особливостям діяльності видавництва «Літопис Української Повстанської Армї̈. Мета пропонованої статті - висвітлити роль комбатантських організацій у діяльності «Літопису УПА»; співпрацю видавництва 3 українськими науковими інституціями, проаналізувати тематичну наповненість його видань.

Для реалізації планів видання «Літопису УПА» засновано при Головній управі Об'єднання колишніх вояків УПА (ОКВ УПА) окрему редакційну колегію. В ї склад ввели чотирьох членів: доктора М. Ріпещького, який був призначений головою, професора, доктора П. Потічного, М. Федака та письменника Д. Мірчука. Допомагати редакційній колегіï зобов'язалися всі члени Головної управи та всі станиці ОКВ УПА на Північноамериканському континенті [23, p. 65].

У березні 1976 р. М. Ріпецький від імені редколегії звернувся до Товариства колишніх вояків УПА (ТКВ УПА) США і Канади з пропозицією про співпрацю в справі видання «Літопису УПА». Керівництво ТКВ УПА позитивно відгукнулося на неї і рекомендувало ввести до складу редколегї своїх представників М. Кулика (голову Товариства) та В. Макара (редерента інформації та видавничої справи Товариства) [18, арк. 1].

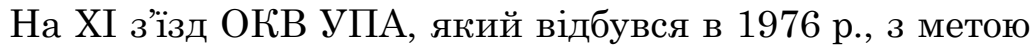
зміцнення співпраці в справі видання «Літопису» були запрошені керівники ТКВ УПА. У прийнятій з’їздом резолюції ще раз наголошувало на необхідності прискорити видання «Літопису УПА», яке друкуватиме документи, матеріали і наукові дослідження історії УПА й взагалі історії України часів Другої світової війни. Видання планувалося здійснювати на академічному рівні [17, арк. 19]. 
Виклад основного матеріалу. 11-12 грудня 1976 р. у Торонто, на першому пленарному засіданні видавничого комітету за участю представників ОКВ УПА та ТКВ УПА створено автономну установу «Видавництво Літопису УПА», в склад якої увійшли члени обох комбатантських організацій УПА [5, с. 19-20].

На цьому засіданні було прийнято правильник (статут) видавництва. В ньому наголошувалося, що метою i завданням видавничого комітету $\mathrm{e}$ «опрацьовувати, опубліковувати і розповсюджувати серійно-книжкові випуски-збірники документів, матеріалів та праць 3 історії Української Повстанської Армії та історії України під час і після Другої світової війни». ХІІ-й з'їзд ОКВ УПА в травні 1979 p. своїм рішенням затвердив статут видавництва «Літопису УПА» [17, арк. 19].

У статуті вказувалося, що всі випуски «Літопису УПА», починаючи 3 другого числа, будуть спільними виданнями Об'еднання колишніх вояків УПА в США і Канаді та Товариств колишніх вояків УПА в США і Канаді. Всі подальші зміни у складі видавців повинні розглядатися на пленарних засіданнях видавничого комітету [5, с. 104].

Для належної організації роботи відповідно до статуту видавничий комітет створив свої керівні органи: президію, редакційну колегію та адміністрацію, представництво яких було розподілено між членами обох співзасновників на паритетній основі. Справами видавництва керувала президія, яка складалася 3 дев'яти осіб: голови видавничого комітету, заступника голови, секретаря, відповідального редактора, адміністратора та чотирьох членів. До складу президії входили голови і перші заступники голів комбатантських організацій [5, с. 105].

У склад першої президії видавничого комітету увійшли М. Ріпецький, М. Ковальчин, Є. Штендера, В. Макар, Я. Струтинський, С. Голяш, M. Miryc та М. Кулик, який тривалий час був ще й адміністратором та організатором фондів та майже 25 років очолював головну управу Товариства колишніх вояків УПА. За роки існування видавництва його головами були М. Ріпецький, Л. Футала, Ю. Котляр та М. Лущак [4]. 
До складу першої редакційної колегії було обрано відповідальних співредакторів - члена ОКВ УПА США і Канади Є. Штандеру та доктора історії й політичних наук Мекмастерського університету в Гамільтоні, члена ОКВ УПА П.Потічного, а також С. Голяша, В. Макара, Б. ЯньоКрука, П. Миколенка, Я. Струтинського, М. Ріпецького, М. Бохна, А. Дольницького, Л. Футала та М. Федака.

Відповідно до законів Канади і провінції Онтаріо новостворене видавництво було зобов'язане пройти реестрацію. 30 травня 1977 р. внесено прохання до Міністерства споживчих і комерційних відносин провінції Онтаріо про реестрацію видавництва «Літопис УПА» як корпорації «без уділового капіталу» з правом публікувати і поширювати серійну публікацію під назвою «Літопис УПА» [5, с. 19-20].

Корпорація зобов'язалася бути неприбутковою і весь дохід вкладати у видавничу діяльність. Члени видавничого комітету погодилися працювати на громадських засадах. 5 січня 1978 р. корпорація отримала патент провінції Онтаріо, підтверджений секціею корпоративної інформації від 21 січня 1978 р. $з$ повним правом виконувати свої завдання [21].

Перші роки в діяльності видавничого комітету були найважчими, оскільки було обмаль не тільки архівних документів чи спогадів колишніх учасників визвольної боротьби УПА, але й технічного обладнання та приміщень. Не було теж жодних фінансових засобів, і починати треба було з нуля. У цих складних обставинах ентузіасти, колишні учасники визвольної боротьби УПА і ОУН почали реалізувати непросту справу - публікувати на рівні наукових вимог об'ективні матеріали про визвольну боротьбу українського народу [18, арк. 10].

До видання «Літопису УПА» залучилося чимало активістів ветеранських організацій, які безкорисно надавали матеріальну і технічну допомогу видавничому комітету та редакційній колегії.

Комбатантські організації активно включилися у справу зміцнення матеріально-технічної бази видавнищтва. 
3 метою накопичення необхідних коштів при видавництві створюеться спеціальний фрінансовий комітет [17, арк. 12].

ОКВ УПА звернулася до всіх членів організації стати передплатниками «Літопису УПА». В 1981 р. число передплатників досягло більше 3 тис. осіб. На жаль, в наступні роки через природне зменшення кількості членів комбатантських організацій УПА чисельність передплатників видання зменшуеться [18, арк. 12].

ТКВ УПА 3 метою збору коштів на потреби видавництва 31978 р. запровадив проведення щорічних збірок. 3 цією метою серед української громади США i Канади ТВК УПА масово поширив спеціальну листівку 3 проханням про допомогу у виданні збірки. Для заохочення кращих спонсорів ТВК УПА друкували їх списки у газетах «Вояцька варта» та «Гомін України». В березні 1984 р. на рахунку видавництва знаходилося 51504 дол., що дозволяло фінансувати два томи видання [18, арк. 26].

У 1975 р. співредактори підготували дві перші книги в основній серії (іï ще називають «канадською серією») під назвами: «Волинь і Полісся». На початку 1976 р. перший том передали до друкарні «Київ» у Торонто. Те, що першими вирішили друкувати матеріали про діяльність УПА на Волині, було не випадковим. Адже саме на цих територіях розпочалася в 1942 р. збройна боротьба УПА з окупантами.

Попри те, що редакційна колегія була нечисленною i проводила роботу на безкоштовній основі, вона прагнула, щоб видання виходили на високому науковому рівні. У своій праці, окрім вже згаданих архівів ЗП УГВР, вона використовувала німецькі архіви та національний архів США, а також Архів ОУН, що складаеться головним чином із колишнього архіву місії УПА, та архів Закордонних частин ОУН. Останній, як зазначає редактор «Літопису» Є. Штендера, не має вартісних матеріалів [18, арк. 43].

У «Літопису УПА» друкувались матеріали мовою оригіналу, 3 дотриманням джерельної точності. Максимально збережена лексика, авторські та редакторські особливості текстів. У кожному розділі було 
вміщено докладні резюме українською мовою, якщо матеріал був не україномовний, i англійською, якщо матеріал був україномовний. У кожному томі було кілька сторінок англійських пояснень, вони були включені також у вступ та висновки. Також подавалися списки скорочень, ілюстрацій тощо [1]. Всього в основній серії цього видання до 2012 р. вийшло 50 томів.

Починаючи 31980 р., видавничий комітет розпочав випуск спеціального «Бюлетеня Літопису УПА». В ньому вміщувалася рецензії на окремі томи «Літопису УПА», детальні списки благодійників видання, розповідалося про діяльність видавничого комітету, повідомлялося про поповнення фондами архіву та бібліотеки видавництва, подавалися автобіографії вояків УПА. Президія видавничого комітету вбачала цінність цього інформаційного обіжника ще й у тому, що широкий загал громадськості міг по ньому оцінювати, яка значна робота проводиться в справі випусків «Літопису УПА» [16, арк. 69; 1].

Про великий авторитет видавництва засвідчило те, що на прес-конференцію, влаштовану 3 нагоди його 10-річчя, прибуло більше 50 осіб, серед них представники Світового Конгресу Вільних Українців (СКВУ), комбатантських та жіночих організащій, кореспонденти провідних українських видань в діаспорі: «Вісті комбатанта», «Гомін України», «Наша мета», «Пластовий шлях», «Юкрейнієн Еко», радіопрограми «Пісня з України». На конференції виступили голова видавничого комітету М. Ріпецький, вичерпну інформацію про 10-річну працю видавництва подав співредактор Є. Штендера [5, с. 173].

Одразу після розвалу СРСР і проголошення незалежної української держави керівництво нашого видавництва розпочало пошук можливостей поширення діяльності також і на українські землі. Йшлося не тільки про розповсюдження вже публікованих матеріалів, а також про доступ до нових джерел інформащії, архівів та, евентуально, залучення нових співпрацівників.

Вже на XIII пленумі видавництва у квітні 1989 р. розпочато обговорення можливостей далекосяжних 
перемін в СРСР та про нові цілі і завдання видавництва. Пленуми видавництва в наступні роки щораз більше присвячували увагу цьому питанню. $\mathrm{У}$ результаті зустрічей, проведених П. Потічним з С. Жеребецьким під час конференщії Міжнародної асоціації україністів, виринула думка створити спільне підприемство в Україні, метою якого було б передруковувати вже видані книги «Літопису УПА» [5, с. 19-20].

Поступово вдалося налагодити контакти 3 дирекцією Інституту української археографрї при Академії наук України (професорами П. Соханем, Г. Боряком та Я. Дашкевичем). Ці контакти стали плідним початком дальшої співпраці між видавництвом «Літопис УПА» i різними науковими та державними інституціями України. На пленарних зборах Видавничого комітету «Літопису УПА» у червні 1992 р. вирішено оформити представництва «Літопису» та зав'язати контакти 3 дослідно-науковими інституціями України. Такі старання зроблено у Львові і Києві влітку того ж року [5, с. 26].

У серпні 1992 р. за участі чотирьох представників видавництва було підписано угоди про співробітництво між Інститутом української археографрї Академії наук України та видавництвом «Літопис УПА». Для того, щоб подолати перешкоди в науково-дослідній роботі в архівах, дирекція Інституту української археографії встановила контакти з Головним архівним управлінням при Кабінеті міністрів України. У вересні 1993 р. відбулася нарада представників Головного архівного управління, видавництва «Літопису УПА» та Інституту української археографії, а згодом (у лютому 1994 р. в Києві) була підписана тристороння угода про наукове співробітництво. Від імені видавництва ऑï підписав М. Ріпецький - один 3 його керівників, багаторічний голова ОКВ США та Канади [5, с. 37; 11].

З 1995 р. випускалася серія, створена редакцією «Літопису УПА» у співпраці 3 Інститутом української apхеографії та джерелознавства ім. М. Грушевського НАН України, Державним комітетом архівів України, 
Центральним державним архівом громадських об’еднань України та Галузевим державним архівом Служби безпеки України. Членом редакційної ради були П. Потічний та Є. Штендера [5, с. 484; 13].

У грудні XVIII з'їзд ОКВ УПА, заслухавши звіт керівника видавництва М. Ріпецького про випуск «Літопису УПА», високо оцінив це видання, назвавши його одним 3 найкращих серед історико-дослідницьких праць в еміграції. З'їзд також відмітив, що досягнути цих успіхів було б неможливо без активної співпраці ОКВ УПА і ТКВ УПА [17, арк. 145].

Видавництво «Літопису УПА» видає також серії «Повстанські могили», «Літопис УПА - бібліотека» та «Події і люди» [2, с. 241-242].

На думку українського дослідника Г. Папакіна, вражае жанрове розмаїття опублікованих томів. Їхня підготовка здійснювалася за тематичною, номінальновидовою, географрічною, інституційною, персоналістською ознаками, а частина взагалі містить мемуарні та меморіальні джерела [12, с. 19].

Основна серія базувалася на документах, що ї рейдуючі частини ОУН та спецкур'ери переправили 3 України у Західну Європу. Це переважно підпільні документи. Більшість із них походить з Архіву зарубіжного представництва УГВР. Винятком е три томи німецьких документів, один том польських та радянських і том документів, які стосуються К. Осьмака.

Частина томів укомплектована за територіальним принципом. Багато уваги у виданнях «Літопису УПА» приділено Волині, де 1942 р. зародилась УПА. Томи 1, 2, 5 і 27 першої серії; 1, 2, 8 і 11 - другої та $1,7,8$ серії «Бібліотека» присвячені саме Волині. Томи 6, 7 і 21 першої серії містять німецькі документи про українське протистояння на цій території. Загалом матеріали про діяльність УПА і збройного підпілля на Волині займають 18 томів [3; 14, с. 251].

Другий регіон, який широко представлено в книгах «Літопису УПА» - Закерзоння. Причиною цього, 
принаймні на початковій стадії роботи над виданням, була досить велика кількість матеріалів із цього терену. Більшість із них передали рейдуючі відділи, а також кур'ери, які курсували між Західною Німеччиною та Україною. До того ж, засновниками й активістами «Літопису УПА» були вихідщі із Закерзоння. Документи 3 тих земель увійшли до томів 13, 14, 16, 17, 22, 28-31, 33, 34, 37, 39 і 40 першої серії (разом 14 книг) [3].

Документи 3 Поділля, переважно 3 Тернопільської області, вміщено в томах 11, 12, 43, 44 і 46 першої серії, Карпатському регіонові (Дрогобиччина та ІваноФранківщина) присвячено томи 3, 4, 18 і 19 першої серії [3].

За змістом видання деякі вчені класифікують наступним чином. Спогади подано у першій серії в томах 5 («Волинь і Полісся. Німецька окупація» перша книга, яка містить декілька спогадів), 15 (спогади К. Гіммельрайха), 18 (спогади групи УПА «Говерла»), 27 (спогади Р. Петренка), 28 (спогади М. Савчин - «Марічки»), 29 (спогади I. Гарасиміва, випускника школи «Олені»), 30 (спогади С. Стебельського та О. Конопадського), 31 (спогади вояків УПА з «Розточчя»), 37 (спогади І. Лика та М. Терефенка); в серї «Бібліотека» в томах 1 (спогади Ю. Ступницького), 3 (спогади Я. Грицая), 4 (спогади В. Левковича, I. Василевського-Путко та ін.). Із 12 книг спогадів найбільш об'емними є спогади М. Савчин «Марічки», які удостоїлися перевидання та видання англійською мовою. Також перевидано спогади Ю. Ступницького, 1 і 2 томи основної серї̈.

Підпільні часописи опубліковано в 7 книгах (разом із книгою, присвяченою УГВР, їх є 8). Том 1 нової серї містить видання (три журнали) Головної Команди УПА. У томах 3 і 4 першої серії передруковано журнал «Чорний ліс», у томі 16 - підпільні журнали Закерзоння, у томі 17 подано англомовні видання підпілля, а в томі 24 журнал «Ідея і Чин» [3].

Декілька книг присвячено біографіям К. Осьмака (т. 41 основної серії), К. Зарицької, (т. 8 серії «Бібліотека») i в 2007 р. до 100-ліття від дня народження генерала 
Р. Шухевича - «Тараса Чупринки» видано дві книги документів (т. 10 нової серії) та спогадів (т. 45 основної серіï), а також брошуру «Нескорений Командир» [3].

У двох томах першої серії - 23 і 32 - зібрано матеріали про медичну службу УПА. Цієї теми торкаються документи з 2 і 8 томів нової серії, а також тому 7 серії «Бібліотека" (автор В. Ковальчук).

Полеглим воякам присвячено два томи першої серії 11 i 36. Перший iз них стосуеться Тернопільщини, а другий - Львівщини. Інформацію про полеглих вояків містять інші книги, наприклад томи 33 , 39, 40, а також книга «Повстанські могили» (про загиблих на Перемищині, Лемківщині, Ярославщині, Любачівщині та Холмщині) [3].

Тексти i ноти понад 600 пісень УПА, які зібрав i профресійно опрацював композитор 3. Лавришин, уміщено в томі 25 основної серії. Том 38 наводить схеми й описи криївок та бункерів УПА, взяті з Архіву внутрішніх військ CPCP [3].

Матеріали УГВР зібрані у 8-10 томах основної серії. Це програмні документи УГВР, матеріали 3 офріційних друкованих видань, протоколи засідань та нарад, інформаційних бюлетенів, спогади членів УГВР тощо [3].

У 6, 7 і 21 томах основної серії подаються документи гітлерівської Німеччини про боротьбу 3 українським націоналістичним підпіллям (головним чином це аналітичні записки, донесення та звіти, підготовлені окупаційною адміністрацією для центральних органів влади в Берліні), а в 22 томі - матеріали (до 1947 р.) про боротьбу 3 українським підпіллям у комуністичній Польщі (це документи військового суду оперативної групи «Вісла», що включають вироки, винесені повстанцям, звіти судових чиновників, внутрішню судову кореспонденцію тощо) [3].

Від початку заснування видавництва в 2012 p. з'явився 100-й том у чотирьох серіях. У зв'язку з цим видавництво випустило «Літопис Української Повстанської Армї. Каталог 100 томів. 1973-2012» [3]. Це конче 
потрібне і надзвичайно корисне видання, бо воно надає дослідникам змогу оперативно знайти відповідний том 3 короткою інформацією про його зміст.

Як доповнене ілюстроване видання від 2004 p. «Літопис» щорічно видає настінні календарі, тематично пов'язані з УПА, в яких відзначено важливі історичні дати, надруковано цікаві фотографії тощо.

Крім власних книг, «Літопис УПА» допоміг побачити світ книжці доктора С. Місила «Повстанські могили» [10], чотиритомному (перевиданому i доповненому) зібранню спогадів ветерана УПА В. Макара «Спомини і роздуми» [6; $7 ; 8 ; 9]$.

Також за сприянням видавництва «Літопису УПА» Канадським інститутом українських студій у 1986 р. видано англомовну працю «Політична думка українського підпілля 1943-1951» [22]. Деякі матеріали цього видання походять зі збірки П. Потічного - архіву «Літопису УПА» при Торонтському університеті. У цій збірці також $є$ повний архів Внутрішніх військ українського округу, частини яких вели боротьбу проти підпілля (за 19441954 pp., понад 150000 сторінок документів) та інші матеріали з архівів Росії та України.

Вирішені наукові завдання й досягнута мета дослідження доводять, що в 40-80-ті pp. ХХ ст., коли Україна перебувала у складі CРCP i ï народ відчув реальну загрозу втрати етнокультурних ознак, саме еміграція продовжила розвивати вітчизняну культуру i науку, зокрема воєнно-історичну. Реалізації цих завдань сприяла наявність в иï середовищі високоосвічених військовиків збройних сил УНР, Української держави, ЗУНР, а також журналістів і митців, які утворили в Польщі, Чехословаччині, Німеччині, Франщії, Канаді й США низку фрахових i творчих об'єднань, наукових, вишкільних і видавничих центрів.

Український воєнно-історичний інститут (УВII) упродовж майже двох десятиріч згуртовував кількасот непересічних дослідників-військовиків, які у складних умовах еміграції створили загалом цільну й об'єктивну 
історіографрію боротьби українців за державність і соборність у першій половині XX ст. Завдяки діяльності Інституту українську військово-історичну науку було гідно репрезентовано у світі. Саме цей інститут видав (замість утраченого у Львові 1939 р.) десятий збірник «За державність (1964р.), а згодом одинадцятий номер (1965 р.). Публікації післявоєнних збірників «За державність відзначалися фраховим науковим i літературним рівнем, виваженими висновками [19, с. 19]. Поряд 3 цим в експозиціях музею $є$ тисячі фрото українських старшин i вояків та епізодів 3 життя українського війська. УВІІ, крім музею, має цей архів цінних документів, бібліотеку і видавництво.

З 1973 р. ТКВ УПА у Канаді спільно з Товариством бувших вояків УПА в США розпочали реалізацію важливого наукового проекту - видання «Літопису УПА», серії книг, у якій публікуються документи і матеріали 3 історії УПА та збройного підпілля ОУН. Довгий час саме матеріали «Літопису УПА» становили основу джерельної бази проблеми ОУН-УПА [5, с. 21; 15, с. 37].

Висновки. Підсумовуючи, варто сказати, що діяльність української еміграції, особливо у сфері воєнно-історичної науки й видавництв міжвоєнної і повоєнної доби, сприяла виходу українського питання на світову арену й певним чином становленню України не лише суб'єктом, але й об'єктом міжнародної політики. Творча спадщина української військової еміграції в галузі історичної науки стала не лише внеском у піднесення національної свідомості та державницького самостійного духу українства, але й нерідко єдиною джерельною базою для сучасних дослідників визвольних змагань українського народу в XX ст. Саме українська військова еміграція створила масив науково-історичних i мемуарноаналітичних творів, які склали джерельну базу для вітчизняних дослідників сторінок воєнної історії. Найбільшим корпусом друкованих джерел з історії ОУН та УПА на сьогодні $є$ серія «Літопис УПА» монументальна пам'ятка боротьби за волю України. 
1. Волянська Л. Серйозне історичне книжкове видання / Л. Волянська // Свобода. - 1980. 28 березня.

2. Енциклопедія історії України: Т. 6: Ла-Мі / [редкол.: В.А. Смолій (голова) та ін.]. НАН України, Інститут історії України. - Кииів, 2009. - 790 с.

3. Літопис Української Повстанської Армії. Каталог ста (100) томів. 1973-2012. - Торонто; Львів, 2012. $124 \mathrm{c}$.

4. Літопис УПА [Електронний ресурс]. - Режим доступу: www.litopysupa.com.

5. Літопис Української Повстанської Армії. Т. 42. Петро Потічний. Літопис УПА. - Історія: документи і матеріали. - Торонто-Львів, 2005. - 658 с.

6. Макар B. Спомини та роздуми: зібрання творів у 4-х т./ В.Макар. - Торонто-Київ, 2001. - Т. 1: Від Бистриці до Бугу (1911-1929). - 448 с.

7. Макар В. Спомини та роздуми: зібрання творів у 4-х т./ В. Макар. - Торонто-Київ, 2001. - Т. 2.: Бойові друзі. - Кн. 1. - 372 с.

8. Макар В. Спомини та роздуми: зібрання творів у 4-х т./ В.Макар. - Торонто-Київ, 2001. - Т. 3: Бойові друзі. - Кн. 2. $-512 \mathrm{c.}$

9. Макар В. Спомини та роздуми: зібрання творів у 4-х т. / В. Макар. - Торонто-Київ, 2001. - Т. 4: Роки неволі та боротьби. $-520 \mathrm{c}$.

10. Місило C. Повстанські могили / С. Місило.Варшава; Торонто, 1995. - 401 с.

11. Павличенко T. Рух національної едності (УНО) / Т. Павличенко. - Вінніпег, 1952. - 67 с.

12. Папакін $Г$. Українські визвольні змагання 19391956: джерельний контекст / Г. Папакін. - Вип. 1. Проблеми класифікації й змісту джерел повстанського та радянського походження / [відп. ред. Г. Боряк]. - Київ, 2012. - 358 с.

13. Потічний П. Політична думка українського підпілля 1943-1951 / П. Потічний // Зустрічі. 1991. - № 2. - C. 137-147.

14. Потічний П. Літопис УПА - документована Історія / П. Потічний, М. Посівнич // Український визвольний рух: наук. зб. - Львів, 2007. - Зб. 11. C. $250-253$.

15. Примаченко Я.Л. Північноамериканська історіографія діяльності ОУН і УПА / Я.Л. Примаченко. Київ, 2010. - 182 с.

16. Центральний державний архів вищих органів влади та управління України (ЦДАВО України). Ф. 5245 (Свген Штендера. Особовий архів 
(Місія УПА за кордоном). Оп. 1, Спр. 180 (Лист та бюлетень Крайової управи Канади Є. Штендері від «Братства колишніх вояків 1-ї дивізії УНА», 4 арк.

17. ЦДАВО України. - Ф. 5245 (Свген Штендера. Особовий архів (Місія УПА за кордоном). Оп. 1, Спр. 376 (Документи, надіслані Є. Штендері від членів «Об’еднання колишніх вояків УПА в США і Канаді» (листування, обіжники, програми з'їдів, протоколи, запрошення, заяви, повідомлення, рахунки, резолюції, вирізки з газет, адреси, конверти, книжкові закладки), 149 арк.

18. ЦДАВО України. - Ф.5245 (Свген Штендера. Особовий архів (Місія УПА за кордоном). Оп. 1, Спр. 453 (Документи про співпрацю С. Штендери 3 «Товариством колишніх вояків УПА в Канаді» (листи, інформаційні матеріали, обіжники, резолюції, вирізки з газет, конверти), 53 арк.

19. ШанковськийЛ. Нарис української военної історіографрії / Л. Шанковський // Український історик. - 1971. - № 3-4. - С. 73-89.

20. Резолюції XIII делегатського з'їзду Об’еднання колишніх вояків УПА США і Канади // Вісті комбатанта. - 1983. - Ч. 4. - С. 102.

21. Ministry of Consumer and Commercial Relations, Letters Patent, Ontario Corporation Number 369498 January 5, 1978.

22. Political Thought of the Ukrainian Underground 1943-1951 / [edited by P. Potichnyj, Y. Shtendera]. Edmonton, 1986. - 406 p.

23. Potichnyj P. My Journey. - Book 4, pt. III: - Toronto; Lviv: Litopys UPA. Series "Events and people», 2012. - $158 \mathrm{p}$. 
Надійшла до редколегії 07.02.2017 p.

Рецензент: М.Р. Литвин, доктор історичних наук, професор, директор Інституту українознавства НАН України імені Івана Крип'якевича, м. Львів.

Лукьянченко С.В. ДЕЯТЕЛЬНОСТЬ ИЗДАТЕЛЬСТВА
УКРАИНСКОЙ ПОВСТАНЧЕСКОЙ АРМИИ»

«ЛЕТОПИСЬ

В статье охарактеризованы особенности организации и тематическое наполнение многотомного издания «Летопись Украинской повстанческой армии» (создано 1976 г. в Канаде) как наибольшего корпуса источников по истории Организации украинских националистов и Украинской повстанческой армии. Показано сотрудничество издательства с научными институтами независимой Украины.

Ключевые слова: Канада, Украина, «Летопись УПА», украинское комбатантское движение.

\section{Lykianchenko S.}

PUBLISHING ACTIVITY OF «CHRONICLE OF UKRAINIAN INSURGENT ARMY» («LITOPYS UPA»)

The article describes edition of "Chronicle of UIA», which started to be published under support of combatant organizations of Canada in the middle of 1970s. It shows cooperation between "Chronicle of UIA» and scientific institutions of independent Ukraine.

Keywords: Canada, Ukraine, "Chronicle of UIA», Ukrainian combatant movement. 